\title{
Extended phraseological information in a valence dictionary for NLP applications
}

\author{
Adam Przepiórkowski, Elżbieta Hajnicz, Agnieszka Patejuk, Marcin Woliński \\ Institute of Computer Science, Polish Academy of Sciences \\ ul. Jana Kazimierza 5, 01-248 Warszawa \\ \{adamp, hajnicz, aep, wolinski\}@ipipan.waw.pl
}

\begin{abstract}
The aim of this paper is to propose a far-reaching extension of the phraseological component of a valence dictionary for Polish. The dictionary is the basis of two different parsers of Polish; its format has been designed so as to maximise the readability of the information it contains and its re-applicability. We believe that the extension proposed here follows this approach and, hence, may be an inspiration in the design of valence dictionaries for other languages.
\end{abstract}

\section{Introduction}

The starting point of the work reported here is Walenty, a valence dictionary for Polish described in Przepiórkowski et al. 2014 and available from http: / zil. ipipan.waw.pl/Walenty (see §1.1). Walenty contains some valence schemata for verbal idioms; e.g., one of the schemata for Kuć 'forge' says that it combines with a nominal subject, a nominal object and a prepositional phrase consisting of the preposition NA 'on' and the accusative singular form of the noun PAMIĘć 'memory' - this represents the idiom ktoś kuje coś na pamięć 'somebody rote learns something', lit. 'somebody forges something onto memory'. The current formalism handles various kinds of verbal phraseological constructions (cf. §1.2), but also has clear limitations. For example, in Polish one may welcome somebody "with arms wide open", and the current formalism makes it possible to express the "welcome with arms + modifier" part, but not the specifics of the allowed modifier, namely, that it is the adjective meaning "open", possibly itself modified by an intensifying adverb (cf. $\$ 1.3$ for details).

The aim of this paper is to propose a new subformalism of Walenty for describing phraseological valence schemata (see §2). To the best of our knowledge, Walenty is already rather unique among valence dictionaries for various languages in paying so much attention to phraseological constructions (among its other rare or unique features), and at the same time it is practically employed in parsing by two different parsers of Polish (cf. §1.1). We believe that these traits make the current proposal to further extend the underlying formalism potentially interesting to the wider audience.

\subsection{Walenty}

Walenty is a valence dictionary which is meant to be both human- and machine-readable; in particular, it is being employed by two parsers of Polish, Świgra (an implementation of a Definite Clause Grammar description of fragments of Polish syntax; Woliński 2004) and POLFIE (an implementation of a Lexical Functional Grammar description of fragments of Polish; Patejuk and Przepiórkowski 2012). As these parsers are based on two rather different linguistic approaches, the valence dictionary must be sufficiently expressive to accommodate for the needs of both - and perhaps other to come.

Each verb is assigned a number of valence schemata ${ }^{1}$ and each schema is a set of argument specifications. Walenty is explicit about what counts as an argument: if two morphosyntactically different phrases may occur coordinated in an argument position, they are taken to be different realisations of the same argument. This is exemplified in the following schema for TŁumaczyć 'explain', as in Musiałem im tłumaczyć najprostsze zasady i dlaczego trzeba je stosować 'I had to explain them the most basic principles

This work is licensed under a Creative Commons Attribution 4.0 International Licence. Page numbers and proceedings footer are added by the organisers. Licence details: http://creativecommons.org/licenses/by/4.0/.

${ }^{1}$ As long as the dictionary contains mostly morphosyntactic information, we avoid using the term valence frame. 
and why they should be adhered to' involving a coordinated phrase in the object position consisting of an NP (najprostsze zasady 'the most basic principles') and an interrogative clause (dlaczego trzeba je stosować 'why they should be adhered to'; marked here as $\mathrm{cp}$ (int)).

$\operatorname{subj}\{\mathrm{np}(\mathrm{str})\}+\mathrm{obj}\{\mathrm{np}(\mathrm{str}) ; \mathrm{cp}(\mathrm{int})\}+\{\mathrm{np}(\mathrm{dat})\}$

There are three argument positions (separated by + ) given in this schema: a subject, an object and an additional argument whose grammatical function is not specified but whose morphosyntactic realisation is described as a dative nominal phrase ( $\mathrm{np}$ (dat)). The subject is also described as a nominal phrase (NP), but its case is specified as structural, i.e., potentially depending on the syntactic context. In Polish, such subjects are normally nominative, but - according to some approaches - they bear the accusative case when they are realised as numeral phrases of certain type. Similarly, the nominal realisation of the object is specified as structural, as it normally occurs in the accusative, unless it is in the scope of verbal negation, in which case it bears the genitive. Crucially, though, the object is specified here not just as an $\mathrm{NP}$, but also alternatively as an interrogative (int) clausal argument ( $\mathrm{cp}$, for complementiser phrase). A parser may take this information into account and properly analyse a sentence with unlike coordination like the one involving TŁUMACZYĆ 'explain', given in the previous paragraph.

Other features of the formalism of Walenty worth mentioning here, and described in more detail in Przepiórkowski et al. 2014, are: the representation of control and raising (cf. Landau 2013 and references therein), specification of semantically defined arguments (e.g., locative, temporal and manner), with their possible morphosyntactic realisations defined externally (once for the whole dictionary), handling of various kinds of pronominal arguments, and other types of non-morphological case specifications (apart from the structural case). While there is no explicit semantic information in the dictionary at the moment (apart from such semantically defined arguments and control information), i.e., no subdivision of verbal lemmata into senses and no semantic role information, Walenty is currently being extended to include such a semantic layer.

\subsection{Phraseology in Walenty}

Two features of the Walenty formalism deal with multi-word expresssions. The simpler one is concerned with complex prepositions such as w KWESTII 'in (some) matter', NA TEMAT 'on (some) topic', z POwODU 'because of' (lit. 'of reason'), etc. Unlike in case of usual prepositional phrases, parameterised with the preposition lemma and the grammatical case it governs (e.g., prepnp ( $z$, inst) for a prepositional phrase headed by $\mathrm{z}$ 'with' and taking an instrumental NP), such complex prepositions seem to uniformly govern the genitive case, so explicit case information is not needed here. The following schema, for ROZPACZAĆ ( $z$ powodu czegoś) 'lament (because of something)', illustrates this type of arguments:

subj\{np (str) $\}+\{$ comprepnp $(z$ powodu $)\}$

Other, more clearly idiomatic arguments are currently specified as fixed, lexnp and preplexnp. Phrases of type fixed again have just one parameter: the exact orthographic realisation of the phrase; see the following schema for zBić 'beat' (as in He beat them to a pulp), with na kwaśne jabłko meaning literally 'into sour apple':

subj\{np(str)\} + obj\{np(str) $\}+\{$ fixed('na kwaśne jabłko') $\}$

A more interesting type is lexnp with four parameters indicating the case of the NP, its grammatical number, the lemma of the head, and the modifiability pattern. The following schema for PLYNĄć 'flow' (as in Hot blood flows in his veins), where the subject is a structurally-cased NP, as usual, but necessarily headed by KREw 'blood' in the singular, and the NP may contain modifiers (cf. atr), illustrates this:

subj\{lexnp (str, sg, 'krew', atr) \} + \{preplexnp (w, loc,pl,' żyła', ratr) \}

The final lexical argument type is preplexnp, which contains an additional (initial) parameter, namely the preposition. In the above schema, the second argument is a PP headed by the preposition w 'in' combining with a locative NP in the plural. The NP must be headed by żYŁA 'vein' and must contain a possessive modifier (ratr stands for 'required attribute'). So this schema covers examples 
such as Goraca krew ptynie w jego żytach 'Hot blood flows in his veins', but - correctly - not the nonphraseological Goraca krew ptynie w żytach (no modifier of 'veins') or Goraca krew ptynie w jego żyle (singular 'vein').

The third possible value of the modifiability parameter is nat $r$, for lexicalised arguments that cannot involve modification. The following schema for zMARzNąć ' get cold, freeze' handles the idiom zmarznać na kość 'freeze to the marrow' (lit. 'freeze to (the) bone'); note that kość 'bone' cannot be modified here, as illustrated by the infelicitous Zmarzł na gota/twardq kośc '(He) froze to (the) naked/hard bone':

subj $\{\mathrm{np}(\mathrm{str})\}+\{\operatorname{preplexnp}($ na, acc, sg, 'kość', natr) $\}$

Finally, batr ('bound attribute'), indicates that the NP must involve a possessive modifier meaning 'self' or '(one's) own', i.e., a form of either swós or wŁaSNY. For example, zoBaczyć 'see' is involved in an idiom meaning 'to see with one's own eyes', as in Na własne oczy zobaczyłem jej uśmiech $i$ to, że nie byta wcale taka stara 'With my own eyes I saw her smile and that she wasn't so old at all': ${ }^{2}$

$\operatorname{subj}\{\mathrm{np}(\mathrm{str})\}+\{\mathrm{np}(\mathrm{str}) ; \operatorname{ncp}(\mathrm{str}, \dot{z} e)\}+$

\{preplexnp (na, acc, pl, 'oko', batr)\}

We will see below that a more expressive - and more general - scheme for the representation of phraseological valence is needed.

\subsection{Limitations}

A number of problems were identified with the formalism of Walenty as it was described in Przepiórkowski et al. 2014 and summarised above. To start with the simplest cases, it is a simplification to say that complex prepositions (comprepnp above) are internally unanalysable and always combine with genitive NPs. For example, while z powodu 'because of' cannot occur without any additional dependents, it is sufficient for the nominal form powodu 'reason' to be modified by an appropriate adjectival form for the whole expression to be complete, e.g., z tego powodu 'because of this', lit. 'of this reason', z waznego powodu lit. 'of important reason', etc. This is not a general feature of such complex prepositions, though. For example, $w$ trakcie 'during', lit. 'in (the) course', must combine with a genitive NP and the nominal form trakcie 'course' cannot be modified by an adjective (*w tym trakcie lit. 'in this course').

Second, it is useful for parsers to have more grammatical information about lexically fixed arguments; for example, fixed('na kwaśne jabłko') clearly has the internal structure of a prepositional phrase.

Third, the current formalism allows for only two types of phraseological phrases to be specified in more detail: nominal (lexnp) and prepositional (preplexnp). While not so frequent, other kinds of idiomatic arguments also occur, including adjectival, adverbial and infinitival. For example, one of the idiomatic uses of mIEć 'have' is mieć przechlapane 'be in the doghouse, be in deep shit', lit. 'have (it) screwed', with an appropriate form of the adjective PRZECHLAPANY 'screwed'. Similarly, the verb DYSZEĆ 'pant' may be argued to optionally require the adverb LEDwo 'barely', as in ledwo dyszeć 'hardly breathe'. Also, KŁAść SIĘ 'lie down' typically occurs with the infinitival form of sPAĆ 'sleep'. The current formalism may describe such requirements only using the rather inflexible fixed notation.

Finally, and perhaps most importantly, modification possibilities within phraseological arguments are far richer than the four symbols atr, natr, ratr and batr could represent. One case in point is the idiom already mentioned in $\$ 1$, namely, witać kogoś $z$ otwartymi ramionami 'welcome somebody with open arms'. The best representation of the idiomatic argument realisation $z$ otwartymi ramionami 'with open arms' is either fixed('z otwartymi ramionami') or preplexnp(z,inst,pl,'ramię', atr) or perhaps preplexnp (z, inst, pl,'ramię', ratr). The first of these does not allow for any modification, so it does not cover z szeroko otwartymi ramionami 'with wide open arms', etc. The second mentions the possibility of modifiers of ramionami (which is the instrumental plural form of the noun RAMIĘ 'arm'), but does not constrain this possibility to (a class of) agreeing adjectives, so it would also cover the non-phraseological z otwartymi ramionami Tomka 'with Tomek's open arms', lit. 'with open

\footnotetext{
${ }^{2}$ The schema is split into two lines solely for typographic reasons.
} 
arms Tomek.GeN'. Also, it makes such modification optional, while witać kogoś z ramionami 'welcome somebody with arms' is at best non-phraseological. Finally, the third possibility makes modification obligatory, but the current meaning of ratr is (for good reasons) constrained to possessive modifiers, so it again does not cover the case at hand, where adjectival modification is present.

\section{Extended phraseological valence}

One more objection against the current subformalism for phraseological arguments, apart from those adduced in the preceding subsection, is that it contains some ad hoc notation, whose meaning is not transparent. The best examples of this are ratr (a possessive modifier, not just any modifier) and bat $r$ (the modifier is a form of swó 'self's' or WŁASNY 'own'). In contrast, we propose a formalism which is not only more expressive, so as to deal with the limitations mentioned in §1.3, but also more transparent. As we will see below, the price to pay for this more expressive and principled formalism is that some argument specifications become more complex.

\subsection{Categories of phraseological arguments}

The first proposed generalisation is to replace category-specific symbols lexnp and preplexnp with the single lex, whose first parameter indicates the category of the phraseological argument. For example, the lexnp (str, sg,' krew', atr) specification given above could be replaced by lex (np (str), sg, ' krew', atr), and preplexnp (w, loc, pl, 'żyła', ratr) by lex (prepnp (w, loc), pl, 'żyła', ratr). Note that the first parameter of lex expresses more than just the grammatical category of the argument - it is the same specification of the morphosyntactic realisation - here, $n p(s t r)$ and prepnp ( $w, l \circ c)$ - as used for non-phraseological arguments. Any (non-lexical, i.e., not lex, etc.) morphosyntactic specification used in Walenty could be used here, including also adjectival, adverbial and infinitival.

For example, for mieć przechlapane 'be in the doghouse, be in deep shit' mentioned above, where the adjective PRZECHLAPANY must occur in the singular neuter accusative and may be modified by an intensifying adverb (mieć kompletnie przechlapane lit. 'have (it) completely screwed'), the appropriate argument realisation could be described as: lex (adjp (acc), n, sg, 'przechlapany', atr). Similarly, the adverb ledwo 'barely' combining with forms of DYszeć 'pant' could be described as lex (advp (misc),' ledwo', natr) (recycling the existing morphosyntactic specification advp (misc) for true adverbial phrases), and the infinitival form of sPAć 'sleep' co-occurring with KŁAŚć sIĘ 'lie down' - as lex (infp (imperf), 'spać', natr) (again, reusing the standard notation for imperfective infinitival phrases, infp (imperf)).

\subsection{Modification patterns}

The most profound generalisation concerns, however, the specification of modification patterns within idiomatic arguments. We propose to retain three basic indicators, namely, natr (no modification possible), atr (modification possible) and ratr (modification required), but - in the case of the last two additional information must be given specifying the kind of modification that is allowed or required. Additionally, atr 1 and ratr 1 are envisaged as variants of atr and ratr with the additional constraint that at most one such modifier may be present. ${ }^{3}$

For example, instead of preplexnp ( $z$, inst, $p l$, 'ramię', rat $r$ ) for $z$ otwartymi ramionami 'with open arms', the following argument specification could be given, explicitly mentioning that the only possible modifier of ramionami 'arms' is an adjectival phrase (and not, say, a genitive modifier): ${ }^{4}$

\{lex (prepnp (z, inst), pl,'ramię', $\operatorname{ratr}(\{\operatorname{adjp}(\operatorname{agr})\}))\}$

Note that morphosyntactic specifications of possible or required modifiers are enclosed in curly brackets, just as in case of direct arguments of verbs, and for the same reason: sometimes multiple morphosyntactic realisations are possible and may be coordinated, which indicates that they occupy the same syntactic position. An example of this is the expression komuś cierpnie skóra na myśl o czymś 'something makes

\footnotetext{
${ }^{3}$ In case of ratr, the obligatoriness of modifier together with this constraint mean that exactly one modifier must occur.

${ }^{4}$ The symbol agr indicates agreeing case here.
} 
somebody's flesh creep', lit. 'somebody.DAT creeps skin.NOM on (the) thought.ACC about something.LOC'. The argument na myśl o czymś 'on (the) thought of something' may be realised in at least three ways: as a prepositional phrase as here (prepnp $(\mathrm{O}, \mathrm{lOC})$ ), as a finite clause introduced by the complementiser żE 'that' (cp (że); e.g., komuś cierpnie skóra na myśl, że (to się stało) lit. 'somebody.Dat creeps skin.NOM on (the) thought.ACC that (this happened.REFL)'), or as a so-called correlative phrase which shares features of the first two realisations, e.g., na myśl o tym, że (to się stało) lit. 'on (the) thought about this.Loc that (this happened.REFL)' (prepncp $(O, 1 \circ c, \dot{z} e)$ ). Such a disjunctively specified modification possibility may be expressed as follows (with the line broken for typographic reasons and indented for readability):

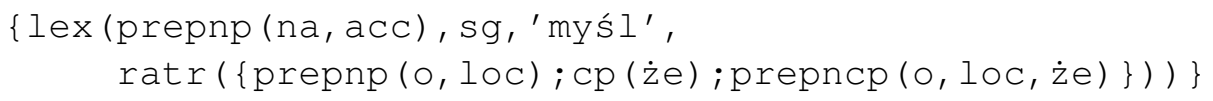

This specification is still incomplete: the noun myśl may also be modified by an adjectival form, e.g., the adjectival pronoun tę, as in skóra mi cierpnie na tę myśl 'this thought makes my flesh creep', lit. 'skin.NOM me.DAT creeps on this.ACC thought.ACC'. This means that adjp (agr) must be added as a possible modifier type. But the status of this modifier type is different than the three modifier types given above: no two of these three phrases can co-occur unless they are coordinated, but any of them can co-occur (and cannot be coordinated) with adjp (agr), e.g., skóra mi cierpnie na sama myśl o tym 'the sheer thought makes my flesh creep', lit. 'skin.NOM me.DAT creeps on sheer.ACC thought.ACC about this.Loc'. Hence, the two kinds of modification possibilities are analogous to two different arguments (here, actually, dependents) of a predicate occupying different syntactic positions, and the same notation could be used to specify them, with the + symbol:

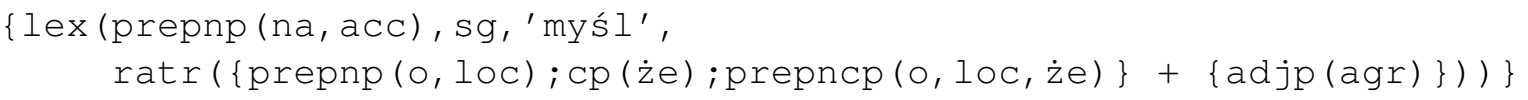

Such argument specifications involving lex may get even more complex due to the fact that lex may occur inside modification specifications of another lex, as in the following description of arguments such as $z$ otwartymi ramionami 'with open arms', more accurate than the one given at the beginning of this subsection:

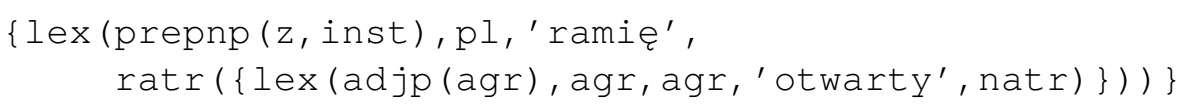

Note that lex(adjp(agr), agr,agr, 'otwarty', natr) replaces adjp(agr) within ratr and it specifies that not just any agreeing adjective phrase may modify the nominal form rękami 'arms', but only the simple adjective phrase consisting of an agreeing form of OTWARTY 'open' does. ${ }^{5}$

As discussed above, this is still not a complete description of the range of possibilities here, as the adjective otwartymi 'open' may itself be modified (contrary to the natr specification above), namely, by the adverb szeroko 'wide'. A closer approximation is given below: ${ }^{6}$

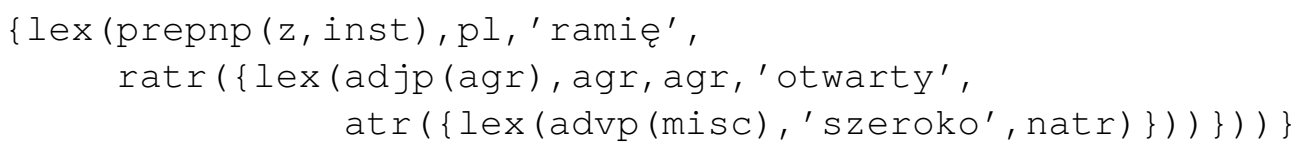

Note that this extension, with the possibility of lex recursion (of the centre-embedding type; Chomsky 1959), makes the language of schema specifications properly context-free.

\subsection{Complex prepositions and fixed arguments}

As noted in $\S 1.3$ above, the notation comprep (...) (e.g., comprepnp ( $z$ powodu)) is not sufficient to model various combinatory properties of complex prepositions: some of them (e.g., z powodu 'because of') may combine with a genitive NP or an agreeing adjective phrase, others (e.g., $w$ trakcie 'during') may only co-occur with an NP, etc. We propose to reuse the lex notation to describe complex prepositions in a more satisfactory manner. For example, one of valence schemata of UMARTwiAć

\footnotetext{
${ }^{5}$ Recall that if $\operatorname{adjp}(\ldots)$ is the first parameter of lex, the next two indicate gender and number, hence the two agrs after adjp (agr) .

${ }^{6}$ Sporadic examples of z bardzo szeroko otwartymi ramionami 'with arms very wide open' (note the additional bardzo 'very') may be found on the internet, but we draw the line here and do not model such occurrences.
} 
SIĘ 'mortify oneself', which specifies such a comprepnp ( $\mathrm{z}$ powodu) argument, could specify it the following way instead (with '_' indicating any number here):

$\{$ lex (prepnp (z,gen) , _,'powód', $\operatorname{ratr}(\{\operatorname{np}(\operatorname{gen}) ; \operatorname{ncp}(\operatorname{gen}, \dot{z} e)\}+\{\operatorname{adjp}(\operatorname{agr})\}))\}$

In contrast, the requirement of $w$ trakcie (where the noun must be in the singular and adjectival modification is not possible) could be spelled out this way:

$\{$ lex (prepnp (w, inst), sg, 'trakt', $\operatorname{ratr}(\{\mathrm{np}(\mathrm{gen}) ; \operatorname{ncp}(g e n, \dot{e} e)\}))\}$

As far as we can see, all complex prepositions could be described this way. On the other hand, there are cases of fixed arguments which could not be so described simply because they contain forms which cannot be specified with a reference to a lemma and morphosyntactic categories such as case or number. One example is the argument of the form fixed (' dęba'), with the form dęba 'oak.GEN' of the noun DĄB 'oak', which co-occurs with forms STANĄć 'stand' in the idiomatic expression stanać dęba 'rear' (of a horse), lit. 'stand oak'. However, since the form dęba is not used in contemporary Polish (the contemporary genitive of DĄB is $d e ̨ b u$ ), this idiomatic argument cannot be expressed as lex (np (gen) , sg, ' dąb', natr), as then parsers would try to analyse the non-phraseological (at best) sequence stanq̨ć dębu as idiomatic. Instead, we propose to extend the fixed notation and add a parameter describing the general morphosyntax of such an argument, e.g., fixed (np (gen) ,' dęba' ).

However, such fixed arguments with forms not attested in contemporary Polish are extremely rare and we envisage that almost all other specifications currently involving fixed can be translated into perhaps more precise specifications involving lex. For example, fixed ('na kwaśne jabłko'), used in zbić na kwaśne jabłko 'beat into a pulp', literally meaning 'into sour apple', may be specified as follows:

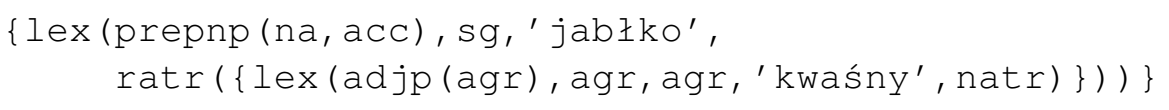

\subsection{Syntactic sugar}

There are two types of syntactic sugar that we would like to propose together with the above extensions. First of all, while it seems that the comprepnp notation for complex prepositions should be replaced by lex, we propose to leave such comprepnp specifications in the dictionary proper and define them in terms of lex specifications separately. The reason for this is that once a complex preposition occurs in the specification of a valence schema, it has the tendency to occur in many schemata; for example, comprepnp ( $\mathrm{z}$ powodu) occurs in 126 schemata in the March 2014 version of Walenty. Replacing all these occurrences with the considerably more complex lex specification given above would diminish the readability of the dictionary. Instead, comprepnp (' z powodu' ) (perhaps with inverted commas, to increase notational consistency) should be left in particular schemata and it should be defined in terms of lex once for the whole dictionary. ${ }^{7}$

The other kind of abbreviatory notation is best illustrated with idiomatic arguments which have so far required the batr modification indicator. Recall that batr means that a given noun may be modified by forms of either of the two adjectives meaning 'self's, own', i.e., forms of swós and wŁasNy. One example is the verb sPRóBowAĆ 'try', which may combine with the expression swoich/wtasnych sit 'one's power' rendering spróbować swoich/własnych sit w czymś 'try one's hand at sth', lit. 'try one's powers in something'. Given the notation introduced so far, this argument would have to be specified as follows:

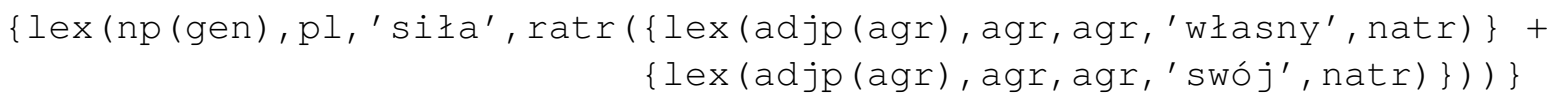

This is not only hardly readable, but also misses the generalisation that the two possible modifiers are just the same kinds of adjectival phrases differing only in the lexical realisation of the adjective meaning 'self's, own'. We propose abbreviating such specifications as follows, with the use of OR:

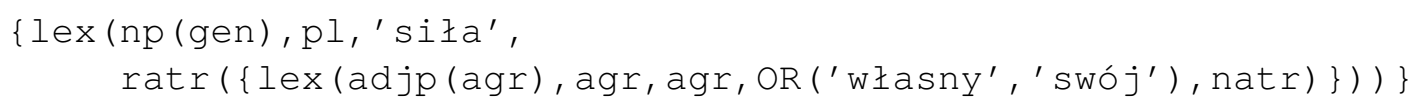

\footnotetext{
${ }^{7}$ This move would be analogous to specifying externally morphosyntactic realisations of semantically defined arguments such as $\mathrm{xp}$ (locat) or $\mathrm{xp}$ (temp) (see Przepiórkowski et al. 2014 for details).
} 
While we could have reintroduced the batr notation to make this even more readable, this symbol is not used in Walenty uniformly, so it would make sense to replace it with more explicit notation involving lex. In particular, some argument specifications mentioning batr actually allow only for forms of wŁASNY, not swós. This is, e.g., the case with DORĘCzYć 'hand (over)', as in doręczyć do rąk własnych (but not doręczyć do rąk swoich) 'deliver as hand delivery', lit. 'hand to own hands', where the specification of the relevant argument in terms of lex explicitly mentions only one of these two adjectives:

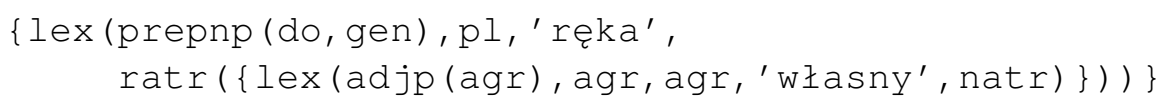

Note finally that this shorthand notation is useful not just in cases involving batr in the old formalism. One case in point is the expression coś strzelito komuś do głowy 'something came over somebody', lit. 'something.NOM shot sombody.DAT to head.GEN', where the form of GLOWA 'head' may be replaced by analogous forms of other nouns with the same meaning, including LEB and LEPETYNA, as specified below: ${ }^{8}$

\{lex (prepnp (do, gen), sg, XoR ('głowa', 'łeb','łepetyna'), atr (\{adjp (agr) \})) \}

\section{Case study}

In the current (as of the end of April 2014) version of Walenty, there are 7 complex prepositions used 691 times (in the schemata of 367 different verbs), 17 fixed phrases used 82 times (36 verbs), 177 lexnp phrases used 686 times (393 verbs) and 238 preplexnp phrases used 1133 times (496 verbs). The last two contain 1182 natr parameters, 217 ratr parameters, 40 batr parameters and 406 atr parameters. Summing up, there are 439 different lexicalisations used in 2567 schemata of 659 verbs. This means that the representation of idiomatic schemata is already non-negligible, and it is bound to increase, as more emphasis is put on such schemata in the current development of Walenty. Hence, the proposed changes - if adopted - will involve substantial interference into an existing resource, and may have a potentially adverse impact on the development of the lexicon, if the formalism proves to be too difficult for lexicographers. This section describes an experiment investigating this issue.

We selected 84 schemata of 36 verbs and asked two main lexicographers involved in the development of Walenty to rewrite these schemata using the proposed formalism. The schemata include $38 \mathrm{fixed}$ arguments, 10 comprepnp arguments, 17 lexnp arguments and 28 preplexnp arguments. The last two contain 22 natr parameters, 6 ratr parameters, 4 batr parameters and 8 atr parameters. The schemata were selected manually, taking into account their frequency, diversity of types of lexicalisations and their parameters, as well as the expected difficulty of rewriting them. This is the reason for the overrepresentation of fixed phrases, which need to be completely reanalysed. We chose multiple schemata for the same verb, to give lexicographers the possibility to join them into a single schemata, given the more expressive new formalism. In particular, all 12 lexicalised schemata for the verb sTAĆ 'stand' were selected for the experiment.

The two lexicographers worked on the textual format of the dictionary (cf. http://zil.ipipan . waw.pl/Walenty) without any support from a tool verifying the syntax of the schemata, etc. Correspondingly, when comparing their results, we ignored purely syntactic errors, including differences in bracketing etc., as such errors can be prevented by such a dedicated tool.

After ignoring such trivial differences, 34 of 84 schemata were found to be encoded differently by the two lexicographers. The differences included 3 cases of a wrong lemma, 5 cases of different values of grammatical categories of case, number, etc., and 7 differences concerning the introduction of new nonlexicalised arguments or merging schemata on the basis of the coordination criterion mentioned in $\S 1.1$. These differences are not directly connected with the proposed changes of the formalism for lexicalisations. Moreover, 9 differences concerned using ( $r$ ) atr instead of ( $r$ ) at $r 1$ (cf. §2.2) where a single realisation of a modifier is possible, as in the following (correct) argument specification for PRZEMARZNĄć 'freeze' surfacing in przemarznać do szpiku kości 'freeze to the bone', lit. 'freeze to (the) marrow (of) bone(s)':

\footnotetext{
${ }^{8}$ This argument specification uses XOR instead of OR as only one of the lexemes meaning 'head' may be used at a time, unlike in the previous case, where forms of both swó and wŁASNY could be used simultaneously: spróbować swoich wtasnych sit $w$ czymś lit. 'try one's own forces in something'.
} 
\{lex (prepnp (do,gen), sg,' szpik', $\operatorname{ratrl}\left(\left\{\operatorname{lex}\left(\mathrm{np}(\mathrm{gen}), \mathrm{pl},{ }^{\prime}\right.\right.\right.$ kość', natr) \})) \}

Since kości must appear exactly once, ratr 1 instead of rat $r$ should be used here. Obviously, guidelines for lexicographers should emphasise this point.

Finally, 17 differences concerned core aspects of the new formalism, such as different modification patters (5), the lack of the morphosyntactic type for fixed (3) and an incorrect specification of the morphosyntactic type of lex, e.g., lack of aspect of infp (2). We judged 6 of them as considerably difficult cases of $f$ ixed lexicalisations, rewriting of which was not at all obvious. One such difficulty concerned an idiomatic use of wYJść 'exit' as in ktoś wyszedt za kogoś za maż 'somebody married somebody else' (of a woman marrying a man, not the other way round), lit. 'somebody.NOM exited PREP ${ }^{9}$ somebody.ACC PREP husband'. The problem lies in the za maż 'PREP husband' part, where maż could be analysed as the regular nominative, but then it would be unexpected that the preposition $z a$ occurs with a nominative noun (it normally combines with the accusative and the instrumental), or as an idiosyncratic accusative form only occurring in this idiom, similarly to dęba mentioned above occurring in stanać dęba 'rear' in this case the exceptional use of fixed would be justified, even though the use of fixed was explicitly discouraged in this experiment. The two specifications of the argument za maz given by the two lexicographers are cited below ${ }^{10}$.

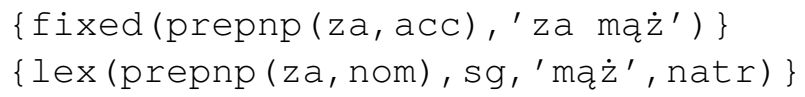

In summary, we feel that the experiment showed that the new formalism is relatively clear and can be learnt by lexicographers, given some training. Support provided by a dedicated lexicographic tool should reduce the number of errors, especially syntactic inconsistencies. On the other hand, the experiment confirmed that some of the most difficult lexicalisations are those currently marked as fixed, and they clearly require special attention.

\section{Discussion and conclusion}

Many valence dictionaries mark some valence schemata as idiomatic - this is true, e.g., of the VALBU valence dictionary for German developed at the Institut für Deutsche Sprache (Schumacher et al. 2004; http://hypermedia.ids-mannheim.de/evalbu/), of the VALLEX dictionary of Czech developed at the Charles University in Prague (Lopatková et al. 2006; http://ufal.mff .cuni.cz / vallex/), as well as some previous valence dictionaries of Polish, including Polański 1980-1992 and the dictionary that was used to bootstrap the first version of Walenty, i.e., Świdziński 1998. However, we are not aware of another valence dictionary that would explicitly describe lexicalised arguments at the same level of detail as the version of Walenty presented in Przepiórkowski et al. 2014. Regardless of this level of detail, though, the formalism employed in that version suffers from a number of problems discussed in $\S 1.3$, limiting its ability to describe phraseological constructions precisely.

In this paper, we propose a far-reaching extension of the formalism of Walenty, making it possible to describe the syntactic structure of a lexicalised argument to any necessary depth. As noted in $\$ 2.2$, the proposed extension makes the description language properly context-free, but this does not seem to be a problem for parsers employing the valence dictionary. On the contrary, as the parsers of Polish become more sophisticated and are developed with full semantic parsing in view, they need precise description of valence schemata that makes it possible to reliably distinguish idiomatic arguments from non-idiomatic compositional constructions.

The need for such deeper description of phraseological arguments in valence dictionaries has occasionally been expressed in the literature, e.g., by Žabokrtský (2005, 65-66, fn. 20), who notes that "[i]n case of multiword parts of phrasemes, the tree (and not only the sequence of forms) representing this part should be ideally captured in the lexicon...". This makes us hope that the current proposal will prove interesting also for the developers of valence lexica for languages other than Polish.

\footnotetext{
${ }^{9}$ The preposition za has a number of different uses and may be translated as 'behind', 'for', 'per', 'by', 'as', etc.

${ }^{10}$ Intuitively, the first representation seems appropriate to us, but we see no strong arguments supporting this intuition.
} 


\section{References}

Noam Chomsky. 1959. On certain formal properties of grammars. Information and Control 2, 137-167.

Idan Landau. 2013. Control in Generative Grammar: A Research Companion. Cambridge: Cambridge University Press.

Markéta Lopatková, Zdeněk Žabokrtský, and Karolína Skwarska. 2006. Valency Lexicon of Czech Verbs: Alternation-Based Model. In Proceedings of the Fifth International Conference on Language Resources and Evaluation, LREC 2006, pages 1728-1733, ELRA, Genoa.

Agnieszka Patejuk and Adam Przepiórkowski. 2012. Towards an LFG parser for Polish: An exercise in parasitic grammar development. In Proceedings of the Eighth International Conference on Language Resources and Evaluation, LREC 2012, pages 3849-3852, ELRA, Istanbul, Turkey.

Kazimierz Polański (ed.). 1980-1992. Słownik syntaktyczno-generatywny czasowników polskich. Wrocław / Cracow: Zakład Narodowy im. Ossolińskich / Instytut Języka Polskiego PAN.

Adam Przepiórkowski, Elżbieta Hajnicz, Agnieszka Patejuk, Marcin Woliński, Filip Skwarski, and Marek Świdziński. 2014. Walenty: Towards a comprehensive valence dictionary of Polish. In Nicoletta Calzolari, Khalid Choukri, Thierry Declerck, Hrafn Loftsson, Bente Maegaard, Joseph Mariani, Asuncion Moreno, Jan Odijk and Stelios Piperidis (eds.), Proceedings of the Ninth International Conference on Language Resources and Evaluation, LREC 2014, pages 2785-2792, ELRA, Reykjavík, Iceland.

Helmut Schumacher, Jacqueline Kubczak, Renate Schmidt, and Vera de Ruiter. 2004. VALBU - Valenzwörterbuch deutscher Verben, volume 31 of Studien zur deutschen Sprache. Forschungen des Instituts für Deutsche Sprache. Tübingen: Narr.

Marek Świdziński. 1998. Syntactic Dictionary of Polish Verbs. Version 3a, unpublished manuscript, University of Warsaw.

Marcin Woliński. 2004. Komputerowa weryfikacja gramatyki Świdzińskiego. Ph.D. dissertation, Institute of Computer Science, Polish Academy of Sciences, Warsaw.

Zdeněk Žabokrtský. 2005. Valency Lexicon of Czech Verbs. Ph. D. dissertation, Charles University, Prague. 